\title{
サリチリデンエチレンジアミン錯体の生成を利用した フローインジェクション法によるベリリウムの蛍光定量
}

\author{
渡辺 邦洋 ${ }^{\circledR}$, 高 橋 章*, 青木伊豆男 ${ }^{* *}$
}

(1991 年 8 月 3 日受理)

\begin{abstract}
弱塩基性水溶液中でベリリウムはエチレンジアミン及びサリチルアルデヒドと反応し，発蛍光性の シッフ塩基錯体を生成する。この反応を利用するベリリウムの FIA 法について検討した。定量範囲は $0.7 \mathrm{ppb} \sim 1 \mathrm{ppm}$ であり, ベリリウム $5 \mathrm{ppb}$ に対する相対標準偏差は $0.68 \%(n=10)$, 分析処理速度は 約 30 検体/hであった. 又トリエ夕ノールアミンの使用によりアルミニウムはベリリウムの 1000 倍量 共存しても妨害せず，更に前処理としてアセチルアセトンを用いた抽出分離を行うことにより，アルミ ニウム地金中に含まれる $0.5 \mathrm{ppm}$ 以上のベリリウムが分析できた．又本法をベリリウム銅合金に適用 した結果も良好であった。
\end{abstract}

\section{1 緒 言}

ベリリウムはさまざまな工業製品に用いられてお $\eta^{1)}$, 製品の特性に対する効果や環境污染の観点から 種々の微量分析が必要とされている.こん跡量のベリリ ウムの定量法としては, モリンを蛍光試薬とする微分シ ンクロナススペクトル法2)や, エリオクロムシアニン $\mathrm{R}^{3)}$ ，クロムアズロール $\mathrm{S}^{4)}$ を用いた吸光光度法などが 高感度分析法として報告されている。

迅速な分析法である FIA としては, キシレノールオ レンジを用いた吸光法 ${ }^{5)} 3$ 3-ヒドロキシ-2-ナフトン酸を 用いた蛍光法 ${ }^{6)}$ が報告されているが，これらは前記のよ うなバッチ法に比べて感度の点で問題がある. 又 ICP-AES を検出器とした FIA 法7) は, 定量下限が 5 $\mathrm{ppb}$ と比較的高感度であるが， 2 重のテフロン管による 抽出を利用しているためシステムがやや複雑である.

一方著者らは, ベリリウムがエチレンジアミン (en) 及びサリチルアルデヒド（SAL）と強い発蛍光性のシッ フ塩基錯体を生成する反応に着目し，バッチ操作による ベリリウムの蛍光定量法を報告した ${ }^{8)}$. この方法は極め て高感度であるが，定量下限付近では励起光の照射に伴 い錯体の分解が見られるため, 再現性が低下する. そこ でこの反応系を，測定条件のコントロールに容易な

* 東京理科大学理工学部工業化学科: 278 千葉県野田 市山崎 2641

** 日本曹達(株)機能製品研究所: 290 千葉県市原市五 井南海岸 12-54
FIA へ適用することについて詳細に検討した結果, ppb レベルのベリリウムを相対標準偏差 1\% 以内で迅速に 定量できた，又同様な反応系で最も高感度であった 5メチルサリチルアルデヒド (MeSAL) と $N, N$-ジメチル 1,3-プロパンジアミン（pn）による反応についても合 わせて検討したが, 試料溶液として使用する $0.05 \mathrm{M}$ 硫 酸の注入により高いから試験值を生じるため, SAL-en 系に比べて定量下限が高かった。

\section{2 実験}

\section{$2 \cdot 1$ 装}

流路系を Fig. 1 に示す. ポンプは日本精密科学製ダ ブルプランジャー型を用い，ポンプによる送液はそれぞ

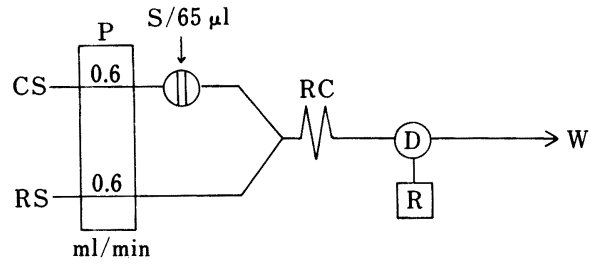

Fig. 1 Schematic diagram of flow system CS: carrier solution; RS: reagent solution; $\mathbf{P}$ : pump; S: sample injector; $\mathrm{RC}$ : reaction coil $(0.5$ mm i.d., $1 \mathrm{~m}$ length); $\mathrm{D}$ : detector (spectrofluorophotometer); Wavelength: excitation/emission $=335$ $\mathrm{nm} / 435 \mathrm{~nm}$ (SAL-en), $350 \mathrm{~nm} / 445 \mathrm{~nm}$ (MeSALpn); R: recorder; W: waste 
れ流量 $0.6 \mathrm{ml} / \mathrm{min}$ で行った。チューブには, 内径 0.5 $\mathrm{mm}$ のステンレス管とステンレス製のコネクターを用い た. 検出器には $12 \mu \mathrm{l}$ フローセル付き島津 RF535 型分 光蛍光光度計を用い, 得られたシグナルはレコーダー上 のピーク高さとして記録した。

\section{$2 \cdot 2$ 試 薬}

ベリリウム (II) 標準溶液: 硫酸ベリリウム $\mathrm{BeSO}_{4}$. $4 \mathrm{H}_{2} \mathrm{O}(99.9 \%) 0.9845 \mathrm{~g}$ を希硫酸に溶解し， $500 \mathrm{ml}$ の $0.05 \mathrm{M}$ 硫酸溶液とした $(0.1 \mathrm{mgBe} / \mathrm{ml})$ 。これを $0.05 \mathrm{M}$ 硫酸で希釈して使用した。

SAL 及び MeSAL: SAL は市販特級品（和光純薬工 業）を用い，MeSAL は Duff 法9)により合成した。いず れもメタノール溶液にして使用した。

en 及び pn: 市販特級品を使用した。

反応試薬液（RS）：RS は次のように調製した。

(SAL-en 系) en $18.1 \mathrm{~g}(20.1 \mathrm{ml})$ をはかりとり, 適 量の水で希釈後, $6 \mathrm{M} \mathrm{HCl}$ 約 $53 \mathrm{ml}$ を添加し $\mathrm{pH} 8.5$ と した。これに $0.1 \% \mathrm{SAL}$ 溶液 $15 \mathrm{ml}$ を添加し, 蒸留水 で $500 \mathrm{ml}$ とした. (MeSAL-pn 系) pn $18.5 \mathrm{~g}$ (22.6 ml) をはかりとり, 適量の水で希釈後, $3 \mathrm{M} \mathrm{NaOH}$ 約 $3 \mathrm{ml}$ を添加し $\mathrm{pH} 12$ とした。これに $0.23 \% \mathrm{MeSAL}$ 溶液 10 $\mathrm{ml}$ と $2 \mathrm{M}$ トリエタノールアミン水溶液 $50 \mathrm{ml}$ を添加し た後, 蒸留水で $500 \mathrm{ml}$ とした。

キャリヤー液 $(\mathrm{CS})$ : 蒸留水を用いた。

\section{3 結果及び考察}

\section{$3 \cdot 1$ 定量条件の検討}

$3 \cdot 1 ・ 1$ 励起, 蛍光スペクトル 生成するベリリウ ムシッフ塩基錯体の補正された励起及び蛍光スペクトル

( I)

(II)<smiles>O=C[N+]12CCN(CC1)Cc1ccccc1O2</smiles><smiles></smiles>

Scheme 1 Beryllium Schiff base complexes

(I) beryllium- $N$-salicylideneethylenediamine; (II) beryllium- $N$-(5-methylsalicylidene) - $N^{\prime}, N^{\prime}$-dimethyl-1, 3-propanediamine

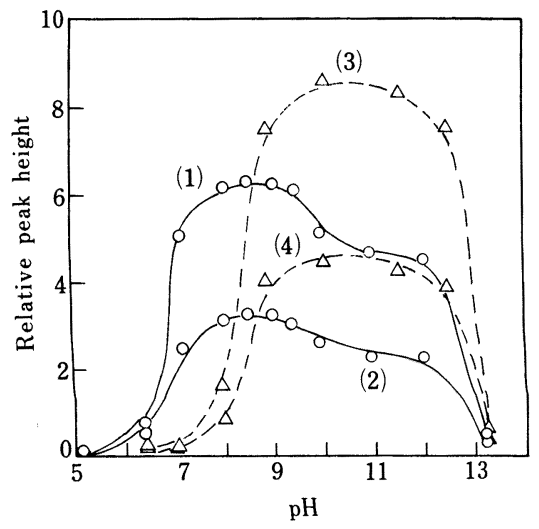

Fig. 2 Effect of $\mathrm{pH}$ of the reagent solution on peak height

(1): Be $100 \mathrm{ppb}$ (SAL-en). (2): Be $50 \mathrm{ppb}$ (SALen); SAL $2.5 \times 10^{-4} \mathrm{M}$; en $1.2 \mathrm{M}$. (3): Be $100 \mathrm{ppb}$ (MeSAL-pn). (4): Be 50 ppb (MeSAL-pn); MeSAL $3.4 \times 10^{-4} \mathrm{M}$; pn $0.6 \mathrm{M}$

は，構造式(I) の錯体が 340 及び $440 \mathrm{~nm}$, 構造式(II) の錯体が 350 及び $455 \mathrm{~nm}$ にそれぞれ極大を示した ${ }^{8)}$. 本研究では蛍光強度の測定はそれぞれの見掛けの極大波 長である 345 及び $435 \mathrm{~nm}$ と 350 及び $445 \mathrm{~nm}$ で行っ た。

3・1・2 pH の影響 $\quad \mathrm{RS} の \mathrm{pH}$ が蛍光強度（ピー ク高さ)に及ぼす影響について調べた。本法においては シッフ塩基形成試薬として用いているアミン成分が $\mathrm{pH}$ 緩衝椷としても作用する. Fig. 2 に示したように, SAL-en 系では $\mathrm{pH} 8$ 8, MeSAL-pn 系では $\mathrm{pH}$ 9.8〜10.5 の範囲で最大かつほぼ一定したピーク高さが 得られ，これはバッチ法息の場合の最適 $\mathrm{pH}$ 範囲とほぼ 一致している．定量操作では試薬溶液の $\mathrm{pH}$ を SAL-en 系, MeSAL-pn 系においてそれぞれ 8.5 及び 10.0 とし た.

3・1・3 SAL 及び MeSAL 湌度の影翌試薬溶液 中の SAL 及び MeSAL 濃度の影響について調べた結果 を Fig. 3 に示す. Fig. 3 より SAL-en 系では SAL 濃 度 $8.2 \times 10^{-5} \mathrm{M} \sim 4.1 \times 10^{-4} \mathrm{M} ， \mathrm{MeSAL}-\mathrm{pn}$ 系では MeSAL 濃度 $2.0 \times 10^{-4} \mathrm{M} \sim 4.7 \times 10^{-4} \mathrm{M}$ の範囲で最大 かつ一定のピーク高さが得られた．更に高濃度になると 蛍光強度は減少しているが，これは過剩シッフ塩基によ る吸収がベリリウム錯体の励起波長及び蛍光波長と重な っているために，励起光及び蛍光の吸収が起こるためで ある ${ }^{8)}$ 。定量操作では試薬溶液中の SAL 及び MeSAL 濃度をそれぞれ $2.5 \times 10^{-4} \mathrm{M}$ 及び $3.4 \times 10^{-4} \mathrm{M}$ とし 


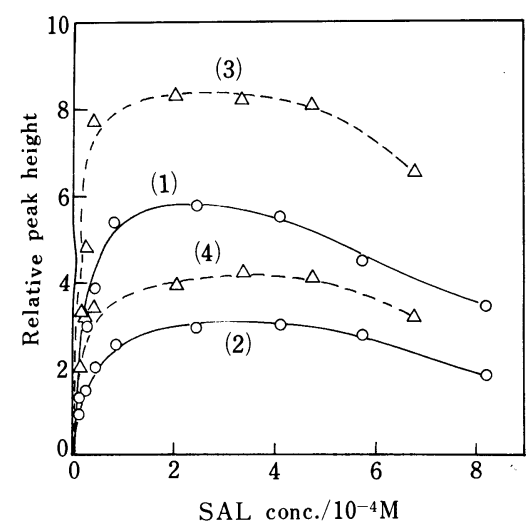

Fig. 3 Effect of concentration of salicylaldehydes on peak height

(1): Be $100 \mathrm{ppb}$ (SAL-en). (2): Be $50 \mathrm{ppb}$ (SALen); $\mathrm{pH}$ 8.5; en $1.2 \mathrm{M}$. (3): Be $100 \mathrm{ppb}$ (MeSALpn). (4): Be $50 \mathrm{ppb}$ (MeSAL-pn); pH 10; pn 0.6 M

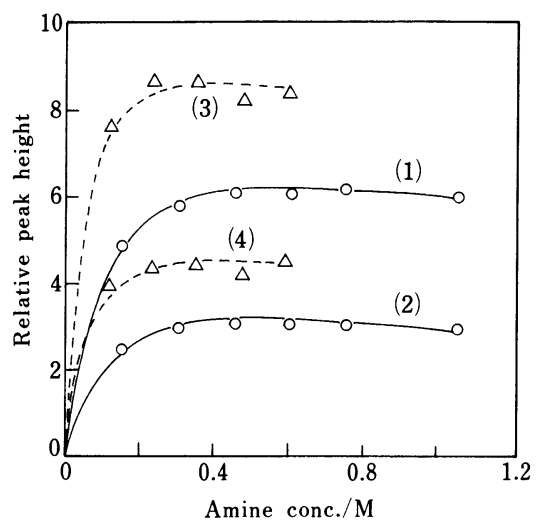

Fig. 4 Effect of concentration of amines on peak height

(1): Be 100 ppb (SAL-en). (2): Be 50 ppb (SALen); pH 8.5; SAL $2.5 \times 10^{-4} \mathrm{M}$. (3): Be $100 \mathrm{ppb}$ (MeSAL-pn). (4): Be 50 ppb (MeSAL-pn). pH $10 ;$ MeSAL $3.4 \times 10^{-4} \mathrm{M}$.

た.

3・1・4 en 及び pn 淟度の影㳅試薬溶液中の en 及び pn 濃度の影響を Fig. 4 に示した. SAL-en 系では en 濃度 $0.45 \mathrm{M}$ 以上, MeSAL-pn 系では $0.24 \mathrm{M}$ 以上 でピーク高さはほぼ一定值を示した。このようにアルデ ヒドに対して大過剰（SAL の場合 1800 倍）のアミンを 必要とするのは, 水溶液中でのシッフ塩基の生成定数が

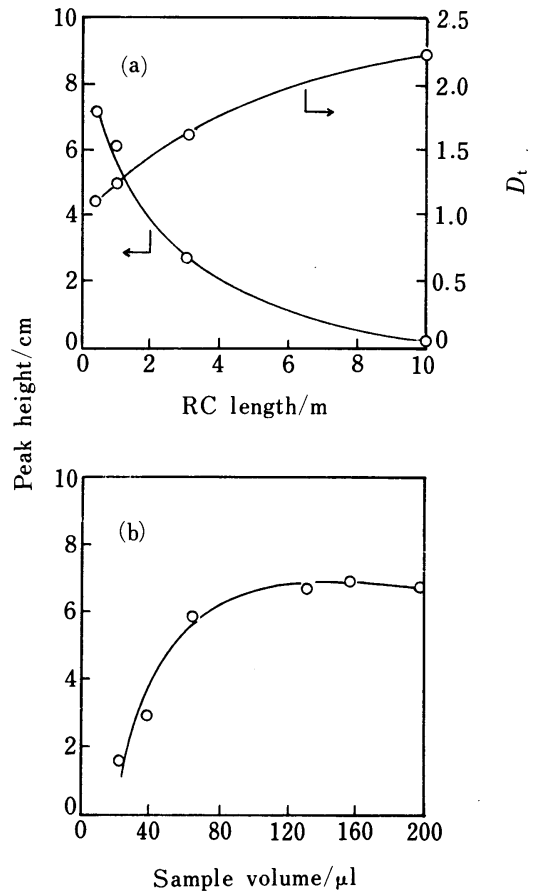

Fig. 5 Effect of reaction coil length (a) and sample volume (b) on peak height

Be $10 \mathrm{ppb}$ (SAL-en); SAL $2.5 \times 10^{-4} \mathrm{M}$; en $0.6 \mathrm{M}$ (in RS); (a) sample volume $65 \mu \mathrm{l}$; $\left(D_{\mathrm{t}}\right.$ : dispersion coefficient); (b) RC length $1 \mathrm{~m}$

小さいためである ${ }^{10)}$. 定量操作では試薬溶液中の en 及 び pn 濃度を $0.6 \mathrm{M}$ 及び $0.36 \mathrm{M}$ とした.

3・1・5 流路系 SAL-en 系において反応コイルの 長さを 0.4〜 $10 \mathrm{~m}$ まで変化させ，ピーク高さに及ぼす 影響を検討した。結果を Fig. 5 に示す。反応コイルが 長くなるほどピーク高さは減少し，これは分散を表す $D_{\mathrm{t}}$ 值 $^{11)}$ の増加率を上回っていることから，いったん生 成した錯体が長い反応コイル中で分解していくものと思 われる. 定量操作では $1 \mathrm{~m}$ の反応コイルを使用した.

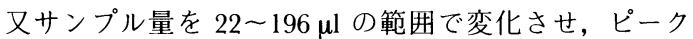
高さへの影響について検討した（Fig. 5). サンプル量 の増加に伴いピーク高さは増大し，65 $4 \mathrm{l}$ 以上でほぼ一 定值を示した．定量操作ではサンプル量を $65 \mu \mathrm{l}$ とし た. 流量については CS と RS の流量の比を $1: 1$ と し， $0.35 \sim 0.95 \mathrm{ml} / \mathrm{min}$ の範囲で，ピーク高さはほぼ一 定值を示した. 定量操作では CS と RS をそれぞれ 0.6 $\mathrm{ml} / \mathrm{min}$ で送液した。

3・1・6 MeSAL-pn 系との比較 バッチ法 ${ }^{8)}$ では 
試薬として MeSAL 及び pn を用いた場合が最も高感度 で, SAL 及び en を用いた場合に比べ約 2 倍の感度で あった。しかし本法では, MeSAL 及び pn を用いた場 合, $0.05 \mathrm{M}$ 硫酸の注入により高いから試験值を生じ, これを抑えるためにトリエタノールアミンの併用が必要 であった。しかしこの場合, ベリリウムも一部マスキン グされてしまうため, 結果的に SAL-en 系に比べ低感 度であった，又精度もより低いものであったため，FIA では SAL-en 系のほうが優れていた。

\section{$3 \cdot 2$ 定量籁囲及び精度}

$3 \cdot 1$ の結果をもとに最適条件においてべリリウムの検 量線を作成した. Fig. 6 に SAL-en 系の定量下限付近 における検量線用フローシグナルの一例を示す. 本法で はベリリウムの標準溶液を $0.05 \mathrm{M}$ 硫酸酸性として用い ているため, Fig. 6 中でベリリウム濃度 0 となってい るのは, $0.05 \mathrm{M}$ 硫酸を注入した場合のピークである. 試薬として作用する遊離のシッフ塩基は, それ自身も弱 い発蛍光性であり, $\mathrm{pH}$ によって極大蛍光波長が変動す るためから試験值としてこのようなピークが観察され る. しかしながら試料の $\mathrm{pH}$ はそれほど厳密である必 要はなく, $\mathrm{pH} 0.8 \sim 1.5$ の範囲であれば一定のピーク高 さが得られる.

作成した検量線はべリリウム濃度 $0 \sim 1 \mathrm{ppm}$ の範囲で 良好な直線関係を示し, 定量下限は $0.7 \mathrm{ppb}$, 検出限界 $(S / N=3)$ は $0.2 \mathrm{ppb}$ であった（MeSAL-pn 系の場合 の定量範囲は, $1 \mathrm{ppb} \sim 0.2 \mathrm{ppm})$. 又ベリリウム $5 \mathrm{ppb}$ に対する相対標準偏差（RSD）は10 回の測定で

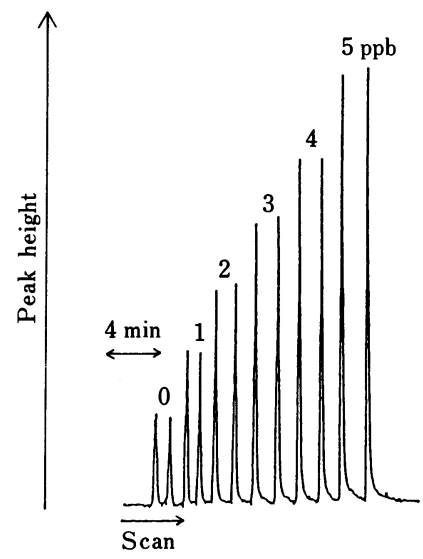

Fig. 6 Flow signals for calibration graphs Be 0 5 ppb (SAL-en); SAL $2.5 \times 10^{-4} \mathrm{M}$; en $0.6 \mathrm{M}$
Table 1 Tolerance limits of diverse ions

\begin{tabular}{cll}
\hline \multicolumn{2}{c}{ Tolerance limit } & \multicolumn{1}{c}{ Ion } \\
\hline 50 & $\mathrm{ppm}$ & $\mathrm{Ba}(\mathrm{II}), \mathrm{Bi}(\mathrm{III}), \mathrm{Cu}(\mathrm{II}), \mathrm{Hg}(\mathrm{II}), \mathrm{Mg}$ \\
& & $(\mathrm{II}), \mathrm{Mo}(\mathrm{VI}), \mathrm{Ni}(\mathrm{II}), \mathrm{Se}(\mathrm{IV}), \mathrm{Tl}(\mathrm{I})$, \\
& & $\mathrm{Zn}(\mathrm{II})$ \\
25 & $\mathrm{ppm}$ & $\mathrm{Ca}(\mathrm{II}), \mathrm{Gd}(\mathrm{II})$ \\
10 & $\mathrm{ppm}$ & $\mathrm{Pd}(\mathrm{II}), \mathrm{Sn}(\mathrm{II})$ \\
5 & $\mathrm{ppm}$ & $\mathrm{Co}(\mathrm{II})$ \\
1 & $\mathrm{ppm}$ & $\mathrm{B}(\mathrm{III}), \mathrm{Ti}(\mathrm{IV})$ \\
0.5 & $\mathrm{ppm}$ & $\mathrm{Al}(\mathrm{III}), \mathrm{Cr}(\mathrm{VI}), \mathrm{Fe}(\mathrm{II}), \mathrm{Fe}(\mathrm{III}), \mathrm{In}$ \\
& & $(\mathrm{III}), \mathrm{Y}(\mathrm{III}), \mathrm{Zr}(\mathrm{IV})$ \\
$0.05 \mathrm{ppm}$ & $\mathrm{Ga}(\mathrm{III})$ \\
\hline
\end{tabular}

$\mathrm{Be}(\mathrm{II})$ added : $0.1 \mathrm{ppm}$

$0.68 \%$, 分析処理速度は約 30 検体 $/ \mathrm{h}$ であった。

\section{$3 \cdot 3$ 共存元素の影掣}

本法（SAL-en 系）における共存元素の影響を Table 1 に示した。 ベリリウム濃度は $0.1 \mathrm{ppm}$ として共存許容 濃度を調べた。

Table 1 に示されるように, 本法の場合, 銅, マグネ シウム, ニッケル，亜鉛などはベリリウムに対して 500 倍量共存しても妨害しないが, ガリウムはベリリウムと 同程度の共存により正の妨害を示した．又 FIA ではバ ッチ法 ${ }^{8}$ に比べて共存元素の許容量が増大しており，こ れは錯体生成の反応速度差によるもの ${ }^{12)}$ と思われる.

\section{$3 \cdot 4$ 実試料への応用}

3•4・1 ベリリウム銅合金への応用 本法 (SAL-en 系）をベリリウム銅合金（日本伸銅協会：Cu 97.71\%， Co $0.268 \%$, Si $0.0579 \%, \mathrm{Fe} 0.0343 \%$ ）へ適用した. 試料 溶液は既報8) と同様にして調製した。試料中のべリリウ ムの標準値 $1.89 \%$ (吸光光度法) に対して, 本法によ る分析值は $1.87 \%(\mathrm{RSD}=1.0 \%, n=5)$ とマスキング 劑の使用なしでも良好な結果が得られた。

Table 2 Masking of aluminium ion with triethanolamine

\begin{tabular}{ccc}
\hline Be added $/ \mathrm{ng} \mathrm{ml}^{-1}$ & Be found $/ \mathrm{ng} \mathrm{ml}^{-1}$ & $\operatorname{RSD}(n=5), \%$ \\
\hline 8.00 & 7.96 & 3.26 \\
16.00 & 16.6 & 1.33 \\
24.00 & 23.7 & 2.35 \\
\hline
\end{tabular}

Each sample contained $15 \mu \mathrm{g} \mathrm{ml}^{-1}$ of aluminium in $0.05 \mathrm{M} \mathrm{H}_{2} \mathrm{SO}_{4}$. 
Table 3 Analytical results of beryllium in aluminium metals

\begin{tabular}{|c|c|c|c|}
\hline \multirow[b]{2}{*}{$\begin{array}{l}\text { Sample } \\
\text { No. }\end{array}$} & \multirow[b]{2}{*}{ Amount of foreign ions, $\%$} & \multicolumn{2}{|c|}{ Be found in the sample, ppm } \\
\hline & & Present method & $\begin{array}{c}\text { Certified } \\
\text { value (ICP-AES) }\end{array}$ \\
\hline 1 & $\mathrm{Si}<0.05, \mathrm{Fe}<0.07, \mathrm{Mg}<4.2$ & $5.74,5.74,6.32,6.55,6.40$ av. 6.15 & 6.0 \\
\hline 2 & $\mathrm{Si}<0.01, \mathrm{Fe}<0.02, \mathrm{Mg}<4.1, \mathrm{Mn}<0.31$ & $1.35,1.26,1.22,1.20,1.42$ av. 1.29 & 1.4 \\
\hline 3 & $\mathrm{Si}<0.06, \mathrm{Fe}<0.07, \mathrm{Mg}<4.5$ & $0.0 \quad 0.0$ & $<0.1$ \\
\hline
\end{tabular}

\section{$3 \cdot 4 \cdot 2$ アルミニウム地金中のベリリウムの定量}

アルミニウム地金中のベリリウムの分析に本法 (SAL-en 系) を適用した. 試料溶液の調製には,アセ チルアセトン吸光光度法 \{LIS（軽金属協会規格） $\left.\mathrm{AOZ}_{-3} 1961\right\}^{13)}$ を準用したが，調製後の試料溶液中に 許容量以上のアルミニウムの共存が予想されるため, ア ルミニウムのマスキングを検討した．マスキング剤とし て EDTA, トリエタノールアミン, 酒石酸ナトリウムに ついて検討した結果, トリエタノールアミンが最も有効 であった．試薬溶液（RS）中に $0.2 \mathrm{M}$ のトリエタノ一 ルアミンを添加し, $\mathrm{pH}$ を 11 とすることにより, アル ミニウムは 1000 倍量共存しても妨害しなかった (Table 2).

上記の RS を使用し, 以下の方法に従いアルミニウム 地金中のベリリウムの分析を行った.

実試料 $1.0 \mathrm{~g}$ を塩酸 $(1+1)$ で加熱分解し, 溶液の一 定量を分取して $10 \%$ EDTA 溶液 $25 \mathrm{ml}, 1 \mathrm{v} / \mathrm{v} \%$ アセチ ルアセトン溶液 $1 \mathrm{ml}$ を加えた後, 直ちに $3 \mathrm{M}$ 水酸化ナ トリウム溶液で $\mathrm{pH}$ を $9.5 \pm 0.2$ に調節した。溶液を分 液漏斗に移し, クロロホルム $25 \mathrm{ml}$ を加えて 2 分間激 しく振り混ぜた.クロロホルム相を $0.1 \mathrm{M}$ 水酸化ナト リウム溶液 $30 \mathrm{ml}$ で 2 回洗净した後, クロロホルム相 をロータリーエバポレーターで留去し, 残留物に 0.05 $\mathrm{M}$ 硫酸 $25 \mathrm{ml}$ を加え, 試料溶液とした。この溶液を Fig. 1 に示した流路系に注入し, ベリリウムを分析し た. 検量線はベリリウム標準溶液に対して試料と同じ操 作を行い作成したものを使用した（Be 10〜 50 ppbに対 する検量線の直線性は良好で，相関係数 0.9997 であっ た).この場合 $\mathrm{RS}$ の $\mathrm{pH}$ は 11 であり, マスキング剤 にトリエ夕ノールアミンを使用することから， MeSAL-pn 系が優れているとの推測も成り立つが, 実
際の測定は再現性と定量下限の点から SAL-en 系が優 れている.

Table 3 に示したように本法による分析値は ICP-AES による分析值とよく一致しており，本法はべ リリウム含有率が $0.5 \mathrm{ppm}$ 以上のアルミニウム試料に 対して有効に適用できる.

アルミニウム地金を提供していただいた，住友軽金属工 業(株)技術研究所の加藤 榮氏に感謝いたします.

\section{$\left(\begin{array}{l}1990 \text { 年 } 10 \text { 月, 日本分析化学会 } \\ \text { 第 } 39 \text { 年会において一部発表 }\end{array}\right)$}

\section{文献}

1) 平野四蔵: “無機応用比色分析 1”, p. 306 (1973), (共立出版).

2) F. G. Sanchez, J. C. M. Gomez, M. H. Lopez: Analyst (London), 112, 649 (1987).

3) 山口典重, 西田妙子, 西田 宏: 分析化学, 38, 48 (1989).

4) 西田 宏: 分析化学, 31, 156 (1982).

5) T. Mochizuki, R. Kuroda: Fresenius' Z. Anal. Chem., 309, 363 (1981).

6) K. Vlastimil, H. Josef, P. Bromislava: Collect. Czech. Chem. Commun., 54(7), 1777 (1989).

7) M. Yamamoto, Y. Obata, Y. Nitta, F. Nakata, T. Kumamaru: J. Anal. At. Spcctrom., 3, 441 (1981).

8) 渡辺邦洋, 青木伊豆男: 分析化学, 34, 497 (1985).

9) J. C. Duff: J. Chem. Soc., 1941, 547.

10) R. W. Green, P. W. Alexander, R. J. Sleet: Aust. J. Chem., 26, 1653 (1973).

11) 上野景平, 喜納兼勇: “フローインジェクション分 析法入門”, p. 23 (1983), (講談社).

12）上野景平, 喜納兼勇: “フローインジェクション分 析法入門”, p. 47 (1983), (講談社).

13）軽金属協会分析委員会編: “アルミニウム中の微 量成分の分析方法”, p. 69 (1978)，(軽金属協会). 
$278 ;{ }^{* *}$ R\&D Laboratory for Speciality Chemicals, Nippon Soda Co., 12-54, Goiminamikaigan, Ichihara-shi, Chiba 290)

Fluorometric determination of Be with Schiff base by flow-injection analysis has been investigated. This method is based on the formation of Be Schiff base complex, by the reaction of ethylenediamine with salicylaldehyde. A dual channel FIA apparatus was used. An aliquot sample solution $(65 \mu \mathrm{l})$ containing less than $65 \mathrm{ng}$ of Be was injected into a carrier stream (distilled water) and was merged with a reagent stream ( $\mathrm{pH}$ 8.5) containing $0.6 \mathrm{M}$ ethylenediamine and $2.5 \times 10^{-4} \mathrm{M}$ salicylaldehyde in $1 \mathrm{~m}$ long stainless steel tubing $(0.5 \mathrm{~mm}$ i.d.), and the mixture was flowed through a flow cell $(12 \mu \mathrm{l})$, at which the fluorescence of the complex was detected $\left(\lambda_{\mathrm{ex}}=335 \mathrm{~nm}, \lambda_{\mathrm{em}}=435 \mathrm{~nm}\right)$. The calibration curve was linear over the range of $0.7 \mathrm{ppb}$ to $1 \mathrm{ppm}$ of $\mathrm{Be}$. The detection limit was $0.2 \mathrm{ppb}(S / N=3)$. The relative standard deviation for $5 \mathrm{ppb}$ of Be was $0.68 \%$ $(n=10)$. The sampling rate was 30 samples per hour. $\mathrm{Al}(\mathrm{III})$ up to 1000 -fold concentration of Be could be masked with triethanolamine. The proposed method could be applied to the determination of Be above $0.5 \mathrm{ppm}$ in $\mathrm{Al}$ metals. In this case, the Be was preconcentrated by the extraction of the Be complex formed with acetylacetone. The results obtained were in good agreement with certified values (ICP-AES).

(Received August 3, 1991)

\section{Keyword phrases}

flow-injection analysis; fluorometric determination of beryllium; salicylaldehyde; ethylenediamine; determination of beryllium in aluminium metal. 